\title{
A corporate social responsibility model for a competitive and resilient hospitality industry
}

By David Daniel Peña-Miranda ${ }^{1}$, Antonio Guevara-Plaza ${ }^{2}$, José Antonio Fraiz-Brea ${ }^{3}$ and Mark Anthony Camilleri 45

Suggested citation: Peña-Miranda, D.D., Guevara-Plaza, A., Fraiz-Brea, J.A., \& Camilleri, M.A. (2021). A corporate social responsibility model for a competitive and resilient hospitality industry. Sustainable Development, 1-14. https://doi.org/10.1002/sd.2259

This is a prepublication version.

\begin{abstract}
Despite in the last decade there was a significant increase in the corporate social responsibility (CSR) literature, little attention has been devoted to shed light on strategic CSR practices in the hospitality industry, especially in the context of developing countries. This paper uses a casestudy methodology to investigate CSR practices of eight hotels in Santa Marta, Colombia. The results show that hotel companies were implementing different CSR behaviors that can be classified as philanthropic-reactive, legal-reactive and active groups. The findings revealed that their CSR activities were intended to add value to their economic performance. Hence, this contribution discusses about these hospitality establishments' individual improvement plans and puts forward a CSR management model for the entire industry. In conclusion, it presents important theoretical as well as managerial implications for practitioners, and proposes future research avenues. The authors suggest that future research should take into account other companies' CSR activities from different industries.
\end{abstract}

Keywords: Corporate social responsibility, tourism, hotels, management model, developing countries.

\footnotetext{
${ }^{1}$ Faculty of Business and Economic Sciences, University of Magdalena, Santa Marta, Colombia.

${ }^{2}$ Faculty of Tourism, University of Malaga, Malaga, Spain.

${ }^{3}$ Faculty of Business Sciences and Tourism, University of Vigo, Vigo, Spain.

${ }^{4}$ Department of Corporate Communication, Faculty of Media and Knowledge Sciences, University of Malta, Msida, Malta.

${ }^{5}$ The Business School, University of Edinburgh, Bucchleuch Place, Edinburgh, Scotland, U.K.
} 


\section{Introduction}

More businesses in service-based industries are increasingly embracing CSR behaviors (Park, Song, \& Lee, 2017). Therefore, CSR has become a popular topic in relevant literature. More academic researchers are exploring CSR practices in different tourism contexts (Font \& Lynes, 2018; Serra-Cantallops et al., 2018). However, there are just a few studies that sought to investigate strategic CSR practices in the hospitality industry, especially in developing countries (Ehsan et al., 2018).

Researchers should bear in mind that CSR is continuously changing and adapting itself to reflect today's realities. It is a dynamic phenomenon that varies according to environmental and social changes, external demands, and the moral maturity of the organizations themselves (Font, Guix, \& Bonilla-Priego, 2006). It is also implemented differently from one location to another, one industry to another, and over time (Guédez, 2010). The successful implementation of CSR is depend on the contextual situation of each company and on its marketing environment in a particular point in time (Lee, Kim, \& Kim, 2018). Consequently, CSR behaviors that are carried out in other industries may not necessarily be replicated in all settings (Wells et al., 2015). Hence, this research is intended to increase academic knowledge and understanding of how CSR initiatives are being carried out in the hospitality industry.

CSR refers to business activities that create a positive impact on society. They may involve a wide range of laudable practices ranging from philanthropic actions and donations to charitable institutions, volunteering, as well as sustainable behaviors like environmental protection, reduction in waste and externalities, et cetera (Camilleri, 2019, 2020; Su \& Swanson, 2017). Several studies postulate that such corporate behaviors can benefit the firm by creating a competitive advantage (Lee, Seo, \& Sharma, 2013), by increasing customer 
satisfaction, trust, and loyalty (Park \& Kim, 2019), thereby boosting profitability and market value (Cho, Chung, \& Young, 2019).

This contribution suggests that CSR is relevant to the hospitality industry due to its connection with the environment and the local communities. Hotels can have an impact on the natural and social environment, for example, through air pollution, noise pollution, waste generation, and will inevitably require additional infrastructure including water and electricity (Chung \& Parker, 2010). The environmental sustainability is strongly related to the destinations' competitiveness and is also positively linked to their economic performance (Zhu, Zhan, \& Shaobo, 2020). In the light of these considerations, this study explores CSR in the hospitality industry, in Santa Marta, Colombia. This city is home to natural, geographic, historical, and cultural resources that position it among the cities with the greatest potential for tourism development.

Drawing on sustainable development (SD) theory, this study uses a case-study methodology and an action research approach to identify, diagnose, and evaluate the CSR practices of eight hotels of different sizes. The hotels are then classified in terms of CSR activities, and a strategic plan is designed for each of them. This contribution builds on previous theoretical underpinnings also puts forward a conceptual model that raises awareness on how CSR behaviors can add value to the businesses as well as to societies, thereby improving destination sustainability and competitiveness. Moreover, it discusses about the managerial implications for industry practitioners, and identifies future research avenues to academia. 


\section{Theoretical Background}

The work of Garriga and Melé (2004) in the area of CSR is among the most rigorous and widely accepted in the scientific literature. These authors classify CSR theories into four groups having to do with benefits (instrumental theories), political action (political theories), social demands (integrative theories), and ethical values (ethical theories).

The present research is associated with ethical theories, since CSR is, first and foremost, an ethical concept (Argandoña \& Hoivik, 2009) that, at its best, leads to sustainability. Companies that base their CSR on ethical theories aim to do the right thing. As a matter of fact, the earliest contributors had associated CSR with corporate philanthropy, stewardship principles and business ethics. Whilst retaining CSR's comprehensive aspects. Generally, they strive to contribute to the common good by implementing normative behaviors (Annan, 1999; Chomali \& Majluf, 2007; Freeman \& Reed, 1983; and Kaku, 1997). Throughout the years, CSR was typically used when evaluating the effects of business on society and the environment (Camilleri, 2017).

Moreover, some of the emerging theoretical underpinnings are increasingly pointing out that CSR is a driver for business and societal benefits (Porter \& Kramer, 2011). In addition, many empirical studies have also proven that there are significant advantages to be gained for the businesses themselves when they engage in socially responsible and sustainable behaviours (Wang \& Choi, 2013; Ameer \& Othman, 2012; Falck \& Heblich, 2007). Many studies investigated various CSR studies at the global level, in different contexts, including in the tourism and hospitality industry. Very often, CSR activities are usually classified based on their economic, social, and environmental dimensions (Peña, Arteaga \& Ramón, 2019) and this classification will be used in the study. 
This model that is based on relevant theoretical underpinnings on the CSR agenda (Carroll, 1991, 1999; De George, 1987; Drucker, 1984; Freeman, 1984; Garriga \& Melé, 2004; Murphy, 1978; Peña \& Serra, 2012; Porter \& Kramer, 2002, 2006, 2011; Sasía \& Valor, 2007; Yepes, Peña, \& Sánchez, 2007; Zadek, Sabapathy, \& Dossing, 2003). Second, it has been adapted in other contributions that were focused on the tourism industry as well as in other sectors (e.g., Sepúlveda et al., 2013; Sepúlveda, Ordoñez, \& Prada, 2014), thereby demonstrating its validity in academic research.

As shown in Table 1, the model makes a classification of companies that carry out CSR practices in order to distinguish the different CSR approaches used by organizations. The classification contains the typology (column 1), the description (column 2) and the type (column 3) and level (column 4) of CSR with the corresponding ranges of quantitative (column 5) and qualitative (column 6) values. Specifically six types of companies are proposed (inactive, philanthropic-reactive, legal-reactive, active, proactive and leader) and for each one is provided a description of their characteristics, the type of CSR (nil, philanthropic, basic, tactical, strategic, integral-sustainable), the level of CSR (based on the following scale: nil, minimum, low, medium, high, maximum), a quantitative evaluation (based on the following scale, $0.0 ; 1.0$ to $1.9 ; 2.0$ to $2.9 ; 3.0$ to $3.9 ; 4.0$ to 4.9 ; and 5,0 ) and a qualitative assessment (based on the following scale: nil, deficient, insufficient, acceptable, outstanding, excellent). In general, the proposed scales were based on six-point Likert scale, very useful and proven in this type of study.

The novelty of this present study is that this contribution uses a chronological approach to classify how the businesses' social responsibility practices have evolved over time. The researchers adopted an action research approach as they applied evaluation parameters to hotels of all sizes (micro, small, medium, large). Hence, they identified the type of company 
(according to its CSR practices), as well as their type and level of CSR in the hospitality industry.

Table 1. Classification of companies according to their CSR practices

\begin{tabular}{|c|c|c|c|c|c|}
\hline $\begin{array}{l}\text { Type of } \\
\text { company }\end{array}$ & Description & $\begin{array}{l}\text { CSR } \\
\text { Type }\end{array}$ & $\begin{array}{l}\text { CSR } \\
\text { Level }\end{array}$ & $\begin{array}{c}\text { Quantitative } \\
\text { Value }\end{array}$ & $\begin{array}{c}\text { Qualitative } \\
\text { Value }\end{array}$ \\
\hline Inactive & $\begin{array}{l}\text { There is no evidence of } \\
\text { any CSR practice, since } \\
\text { the term "social } \\
\text { responsibility" is not } \\
\text { conceived in a formal } \\
\text { way or in a strict sense. }\end{array}$ & Nil & Nil & 0.0 & Nil \\
\hline $\begin{array}{c}\text { Philanthropic- } \\
\text { reactive }\end{array}$ & $\begin{array}{l}\text { Isolated philanthropic } \\
\text { activities can be } \\
\text { observed. }\end{array}$ & Philanthropic & Minimum & $1.0-1.9$ & Deficient \\
\hline $\begin{array}{l}\text { Legal- } \\
\text { reactive }\end{array}$ & $\begin{array}{l}\text { CSR activities are } \\
\text { limited to strict } \\
\text { compliance with current } \\
\text { legislation. }\end{array}$ & Basic & Low & $2.0-2.9$ & Insufficient \\
\hline Active & $\begin{array}{l}\text { Companies begin to } \\
\text { engage in CSR practices } \\
\text { for tactical reasons, even } \\
\text { though they are not } \\
\text { required to do so by law. }\end{array}$ & Tactical & Medium & $3.0-3.9$ & Acceptable \\
\hline Proactive & $\begin{array}{l}\text { CSR is integrated into } \\
\text { business strategy. }\end{array}$ & Strategic & High & $4.0-4-.9$ & Outstanding \\
\hline Leader & $\begin{array}{l}\text { Companies are } \\
\text { committed to the } \\
\text { sustainable development } \\
\text { of society. }\end{array}$ & $\begin{array}{c}\text { Integral- } \\
\text { Sustainable }\end{array}$ & Maximum & 5.0 & Excellent \\
\hline
\end{tabular}

(Source: Peña \& Serra, 2012)

\section{Methodological Approach}

The present research uses an interpretative case-study methodology and, within it, an active research approach. For Yin (2003), a case study investigates a contemporary social phenomenon in its real-life context, while for Eisenhardt (1989), the purpose of a case study is 
to understand the dynamics that are present in a single setting. As CSR should be analyzed in real and unique contexts, the case-study method was considered suitable for to capture and interpret the findings from this research, with the main advantage of obtaining rich information about the environmental context, and from research participants' opinions and beliefs on their company (González, Alén, \& Rodríguez, 2011).

Moreover, the researchers have adopted an action research approach to better understand organizational processes and their behaviors (Ladkin, 2005). This methodology is frequently used in research that investigate organizational theory (Bradbury, 2001). Interesting work has also been done in the field of tourism (Van Der Duim \& Van Marwijk, 2006; Tepelus, 2008), and hospitality research (Font, 2008).

In this light, the practical methodological process consisted of the following stages. Firstly, the researchers carried out a thorough review of the relevant literature on CSR concepts, theories and practices. Secondly, they gathered primary data from a convenience sample of eight hospitality properties that were situated in Santa Marta, Colombia, one of the country's most popular tourism hubs in South America. The researchers have followed Eisenhardt's (1989) recommendations to include a variety of organizations to take part in their inductive case studies. They sought to include different hotel companies of different organizational sizes (and staff counts) including 2 micro hotels (fewer than 10 employees), 2 small hotels (between 11 and 50 employees), 2 medium-sized hotels (between 51 and 200 employees), and 2 large hotels (with more than 200 employees). For confidentiality purposes, the hotels will be referred to as follows: micro hotel 1 (Hmi1), micro hotel 2 (Hmi2), small hotel 1 (Hsm1), small hotel 2 (Hsm2), medium-sized hotel 1 (Hme1), medium-sized hotel 2 (Hme2), large hotel 1 (Hla1), and large hotel 2 (Hla2). In table 2, there is specific information about the hotels and the research participants. 
Table 2. Hotels' information and the research participants

\begin{tabular}{|c|c|c|c|c|}
\hline Hotels Code & Category/classification & Rooms & Years of operation & Informant position \\
\hline Hmi1 & Boutique & 10 & $<10$ & General Manager \\
\hline Hmi2 & 3 stars & 10 & $<10$ & General Manager \\
\hline Hpe1 & Boutique & 12 & $<10$ & General Manager \\
\hline Hpe2 & 3 stars & 75 & $>40$ & General Manager \\
\hline Hme1 & Nil & 72 & $<10$ & General Manager \\
\hline Hme1 & Nil & 134 & $21-40$ & General Manager \\
\hline Hgr1 & Nil & 350 & $>40$ & General Manager \\
\hline Hgr2 & Nil & 330 & $10-20$ & General Manager \\
\hline
\end{tabular}

Thirdly, the interpretative data was gathered through a structured questionnaire that was disseminated among hotel managers. This questionnaire sought information on their organizations' CSR practices. Finally, the qualitative case studies were analyzed, synthesized, and interpreted. The researchers evaluated their research participants' responses on their hotels' CSR practices. They clarified the rationale for their engagement in responsible behaviors and shed light on their companies' economic, social and environmental dimensions. Table 3 clarifies how CSR practices can be categorized according to these three dimensions.

Table 3. Classification of CSR activities by dimension

\begin{tabular}{|c|c|c|}
\hline & & ) \\
\hline $\begin{array}{l}\text { ECA1. CSR is integrated into the } \\
\text { strategy of my business (mission, } \\
\text { vision, values, policy, strategic plan). } \\
\text { ECA2. We are part of an international, } \\
\text { national, regional, or local CSR } \\
\text { initiative (Global Compact, Code of } \\
\text { Ethics for Tourism, GRI, or other). } \\
\text { ECA3. We strive to provide high- } \\
\text { quality products and/or services at } \\
\text { competitive prices (good value for } \\
\text { money). }\end{array}$ & $\begin{array}{l}\text { social action policy and plan. } \\
\text { SOA2. We collaborate directly } \\
\text { and/or indirectly on the social } \\
\text { projects of local communities } \\
\text { (social welfare, development } \\
\text { cooperation, corporate volunteering, } \\
\text { company foundation, NGO, } \\
\text { donations, charity, isolated } \\
\text { philanthropy, loan of facilities, etc.) }\end{array}$ & $\begin{array}{l}\text { ENA1. We have an established } \\
\text { environmental plan and policy. } \\
\text { ENA2. We have a concrete } \\
\text { strategy to deal with global } \\
\text { warming (climate change). } \\
\text { ENA3. We have environmental } \\
\text { certification or are in the process } \\
\text { of earning it. } \\
\text { ENA4. We have identified our } \\
\text { environmental impact and have }\end{array}$ \\
\hline
\end{tabular}




\begin{tabular}{|c|c|c|}
\hline $\begin{array}{l}\text { ECA4. We know the needs, } \\
\text { expectations, and satisfaction levels of } \\
\text { our clients. } \\
\text { ECA5. We give our clients complete, } \\
\text { transparent, and honest information } \\
\text { about the commercial offer, and we } \\
\text { respect their rights. } \\
\text { ECA6. We encourage our clients to } \\
\text { use and consume local products } \\
\text { during their stay (the tourism business } \\
\text { value chain). } \\
\text { ECA7. We hire local personnel at } \\
\text { different levels of responsibility in the } \\
\text { company (low, medium and high). } \\
\text { ECA8. We pay our workers a fair and } \\
\text { decent wage that, at the very least, } \\
\text { complies with existing legislation and } \\
\text { the industry's market prices. } \\
\text { ECA9. We hire local suppliers. } \\
\text { criteria. }\end{array}$ & 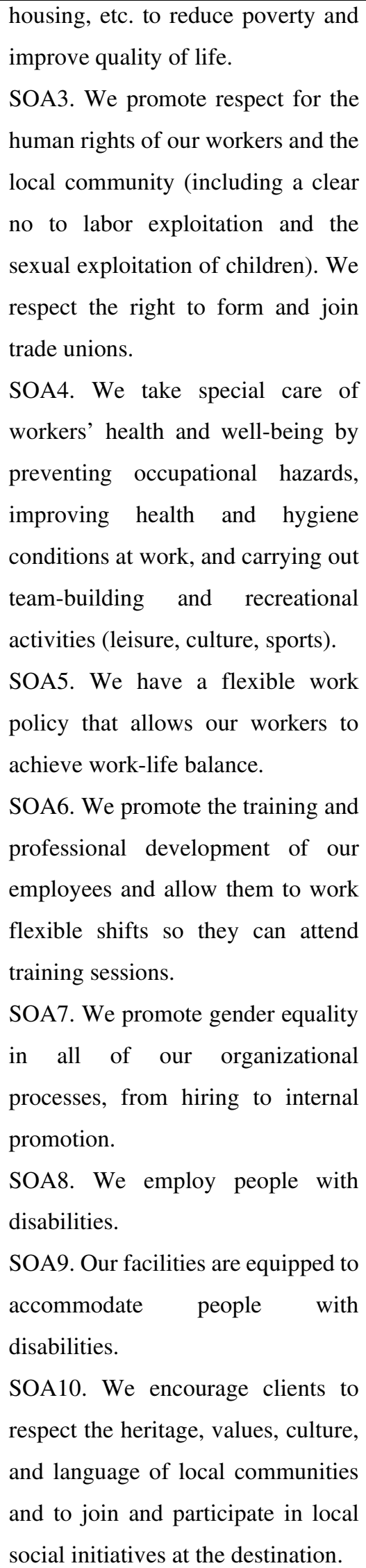 & $\begin{array}{l}\text { taken concrete steps to minimize } \\
\text { it. } \\
\text { ENA5. We have energy-, water-, } \\
\text { and paper-saving strategies } \\
\text { (employees, clients). } \\
\text { ENA6. We use some kind of } \\
\text { alternative energy (i.e., renewable } \\
\text { energy: solar, wind, ocean, } \\
\text { geothermal, biomass, } \\
\text { hydraulic). } \\
\text { ENA7. We have waste reduction, } \\
\text { recycling, sorting, or treatment } \\
\text { programs or systems. } \\
\text { ENA8. We include environmental } \\
\text { aspects in our purchase criteria and } \\
\text { in the selection of our suppliers } \\
\text { and business partners (tourism } \\
\text { business value chain). } \\
\text { ENA9. We encourage our clients } \\
\text { to care for and protect the } \\
\text { environment at their destination. } \\
\text { ENA10. We carry out awareness- } \\
\text { raising campaigns and/or } \\
\text { environmental training for } \\
\text { employees, clients, business } \\
\text { partners, and/or local communities } \\
\text { (tourism business value chain). }\end{array}$ \\
\hline
\end{tabular}

Source: Peña, Arteaga, and Ramón (2019) 
It is relevant to say that the overall quantitative score for each hotel's CSR was calculated as the arithmetic mean of its economic, social, and environmental activities (individually scored by each hotel manager to whom the questionnaire was administered). For the purposes of the present study, they were all assigned the same weight and importance, thereby complying with ethics-based SD theory in the sense of promoting corporate actions carried out within a framework of comprehensive economic, social, and environmental development that ensures a balance of corporate profitability, the natural environment, and society. In summary, in the field, each manager gave an assessment (between 0 and 5) to each of the 30 CSR activities (10 economic activities, 10 environmental and 10 social). In summary to measure CSR practices, the activities listed in table 3 (ECAs, SOAs, and ENAs) was evaluated based on six-point Likert scale from nill to maximum (the rest: minimum, low, medium, high).

As described in table 1 there are six types of companies according to their CSR practices (inactive, philanthropic-reactive, legal-reactive, active, proactive and leader) and each one has a range of quantitative values. To sum up, if the average of all the CSR activities of the hotel is zero, it means that it's an inactive company. Between 1.0 and 1.9 it's a philanthropic-reactive company. Between 2.0 and 2.9 it's a legal-reactive company. Between 3.0 and 3.9 it's an active company. Between 4.0 and 4.9 it's a proactive company. Finally, if the average is 5, it's a leader company in CSR. These ranges of values for each type of company are those established within the model summarized in table 1 explained before, which has already been used in other studies of the tourism sector.

To conclude, an inactive hotel, has no evidence of any CSR practice, since the term social responsibility is not conceived in a formal way or in a strict sense. A philanthropic-reactive hotel carries out isolated philanthropic activities. For legal-reactive hotel, the CSR activities are limited to strict compliance with current legislation. An active hotel begins to engage in CSR practices 
for tactical reasons, even though they are not required to do so by law. Meanwhile, in a proactive hotel, CSR is integrated into business strategy and lastly a leader hotel is committed to the sustainable development of society.

\section{Results and discussion}

The descriptive survey provided useful insights on CSR behaviors in the Colombian hospitality industry. The researchers shed light on the CSR practices of eight hotels in Santa Marta. They put forward their action plans for each hotel and present a CSR management model that is intended to support industry practitioners.

4.1. Identification, diagnosis, and evaluation of CSR at the hotels in the study

The findings revealed that similar-sized hotels were carrying similar CSR practices, as reported in table 4. Specifically, micro and small hotels (global quantitative values: Hmi1=1.6; $\mathrm{Hmi2}=1.7 ; \mathrm{Hsm} 1=1.8$; and $\mathrm{Hsm} 2=1.9$ ) that belonged to the philanthropic-reactive category as they were engaging in altruistic CSR behaviors that were not necessarily related to their business activities. The medium-sized hotels (global quantitative values: Hme1=2.7 and Hme2=2.9) were simply executing minimal CSR practices in order to comply with law and relevant legislations. Consequently, their legal-reactive CSR behaviors did not require a high level of commitment. The larger hotels (global quantitative values: Hla1=3.8 and Hla2=3.9) were considered as CSR-oriented companies as they were actively implementing CSR initiatives that were beyond their legal obligations. They have not yet integrated them into their business strategy, but rather engaged in tactical CSR with a medium level of implementation. 
Table 4. Classification of hotel companies according to their CSR practices

\begin{tabular}{|c|c|c|c|c|c|c|c|c|}
\hline \multirow{2}{*}{ Hotel } & \multirow{2}{*}{$\begin{array}{l}\text { Type of } \\
\text { Company }\end{array}$} & \multirow{2}{*}{$\begin{array}{l}\text { CSR } \\
\text { Type }\end{array}$} & \multirow{2}{*}{$\begin{array}{c}\text { CSR } \\
\text { Level }\end{array}$} & \multicolumn{4}{|c|}{ Quantitative Value } & \multirow{2}{*}{$\begin{array}{c}\text { Qualitative } \\
\text { Value }\end{array}$} \\
\hline & & & & ECAs & SOAs & ENAs & Global & \\
\hline Hmi1 & $\begin{array}{l}\text { Philanthropic- } \\
\text { reactive }\end{array}$ & Philanthropic & Minimum & 2.1 & 1.8 & 1.0 & 1.6 & Deficient \\
\hline $\mathrm{Hmi} 2$ & $\begin{array}{l}\text { Philanthropic- } \\
\text { reactive }\end{array}$ & Philanthropic & Minimum & 2.2 & 2.0 & 1.0 & 1.7 & Deficient \\
\hline Hsm1 & $\begin{array}{l}\text { Philanthropic- } \\
\text { reactive }\end{array}$ & Philanthropic & Minimum & 2.3 & 2.0 & 1.1 & 1.8 & Deficient \\
\hline Hsm2 & $\begin{array}{l}\text { Philanthropic- } \\
\text { reactive }\end{array}$ & Philanthropic & Minimum & 2.5 & 2.0 & 1.1 & 1.9 & Deficient \\
\hline Hme1 & Legal-reactive & Basic & Low & 3.2 & 3.0 & 2.6 & 2.7 & Insufficient \\
\hline Hme2 & Legal-reactive & Basic & Low & 3.2 & 3.0 & 2.6 & 2.9 & Insufficient \\
\hline Hla1 & Active & Tactical & Medium & 4.0 & 3.7 & 3.8 & 3.8 & Acceptable \\
\hline Hla2 & Active & Tactical & Medium & 4.1 & 3.7 & 3.8 & 3.9 & Acceptable \\
\hline
\end{tabular}

In all cases, these businesses' CSR activities were triggered by strategic motives to improve their economic performance. The economic dimension received the highest scores (ECAs quantitative values: Hmi1=2.1; Hmi2=2.2; Hsm1=2.3; Hsm2=2.5; Hme1=3.2; Hme2=3.2; Hla1=4.0; Hla=4.1). This was followed by the social (SOAs quantitative values: Hmi1=1.8; Hmi2=2.0; Hsm1=2.0; Hsm2=2.0; Hme1=3.0; Hme2=3.0; Hla1=3.7; Hla=3.7) and environmental (ENAs quantitative values: Hmi1=1.0; Hmi2=1.0; Hsm1=1.1; Hsm2=1.1; Hme1=2.6; Hme2=2.6; Hla1=3.8; Hla=3.8) activities. These results are consistent with similar results reported in other studies that have also found minimum and low levels of CSR implementation at the global level (Alwyn \& Kiyoteru, 2012), in Latin America (Casado \& Roser, 2009), in Colombia (Atehortúa, 2008), in the tourism industry in general (Tepelus, 2008), and in the hotel industry in particular (Eme et al., 2013).

One interesting finding is that as the larger hotels were more adept in their CSR practices as opposed to their smaller counterparts. Most probably, they had more competences, resources and capabilities, that could have facilitated their CSR performance. The active hotels engaged in tactical activities that went beyond what was legally required by them. Evidently, they realized that there is more to CSR than philanthropy and ethical behaviors. They were 
implementing CSR because it increased their companies' bottom lines. In this regard, the present results are consistent with those that reported that there is a business case for CSR (Corral et al., 2007; Forum Empresa, 2011; Garay \& Font, 2012; Roadmap, 2010; Vives, Corral, \& Isusi, 2005).

This study suggests that hospitality managers are not knowledgeable enough about the positive effects of CSR on their business (Camilleri, 2015; 2017). Their CSR performance can improve their relationships with stakeholders, including employees, customers, and nearby communities, among others, and may lead to increased trust in the company, to a better corporate image and to their improved reputation, among other benefits.

\subsection{Action plans for hotels}

The proposed action plan builds on key theoretical underpinnings that were drawn from relevant academic literature as well as from non-governmental organizations' regulatory instruments and principles (Freeman \& Reed, 1983; Mitchell, Agle \& Wood, 1997; ReyMaquieira et al., 2011; GRI, 2013). The researchers clarify the CSR activities involving internal and external stakeholders as well as environmentally friendly practices can lead to positive economic, social and environmental outcomes. Specifically, the management areas with a direct impact on hotel stakeholders are: senior management; employees; customers; the environment; the local community; investors; suppliers; competitors; research, development, and innovation (henceforth $\mathrm{R} \& \mathrm{D}$, and innovation or $\mathrm{R} \& \mathrm{D}+\mathrm{i}$ ); and government.

The respective plans drawn up based on these criteria are provided in Tables 5, 6 and 7. They were designed taking into account the strengths (scores of 4 and 5) and weaknesses (scores of $0,1,2$, or 3 ) of each management area with regard to the implementation of the $30 \mathrm{CSR}$ activities proposed for this study. It is important to comment that strengths are those CSR activities (from table 1) that were valued (on six-point Likert scale) with 4 or 5 points and 
weaknesses are those CSR activities (from table 1) that were valued with $0,1,2$ or 3 points, being 0 nil and 5 maximum, as explained in the methodology. The plans were grouped by size, in accordance with the results described in Section 4.1, and a maximum of 12 months was recommended for their implementation.

Table 51. Improvement plans for micro and small hotels - Hmi1, Hmi2, Hsm1, and Hsm2

\begin{tabular}{|c|c|c|}
\hline $\begin{array}{l}\text { Management } \\
\text { Area - } \\
\text { Stakeholder }\end{array}$ & Activity & Verification Source \\
\hline \multirow{3}{*}{$\begin{array}{l}\text { Senior } \\
\text { management }\end{array}$} & $\begin{array}{l}\text { Integrate CSR into the hotel's strategy, i.e., its mission, } \\
\text { vision, values, policy, and strategic plan. This latter } \\
\text { document should contain measurable CSR objectives with } \\
\text { comparable, verifiable, and assessable indicators. }\end{array}$ & $\begin{array}{l}\text { Mission, vision, values, } \\
\text { policy, and strategic plan } \\
\text { documents prepared. }\end{array}$ \\
\hline & $\begin{array}{l}\text { Join an international CSR initiative, preferably the Global } \\
\text { Compact, the Global Code of Ethics for Tourism, or the } \\
\text { GRI, and transparently and regularly report on the } \\
\text { progress and achievements in CSR required under it. }\end{array}$ & $\begin{array}{l}\text { Document offering proof of } \\
\text { the commitment to the } \\
\text { Global Compact, Global } \\
\text { Code of Ethics for Tourism, } \\
\text { or GRI and prepared and } \\
\text { published CSR report. }\end{array}$ \\
\hline & $\begin{array}{l}\text { Form a CSR committee, representative of all the hotel's } \\
\text { management areas, responsible for the comprehensive } \\
\text { management of CSR. }\end{array}$ & $\begin{array}{l}\text { Minutes recording the } \\
\text { formation of the committee } \\
\text { with functions. }\end{array}$ \\
\hline \multirow{3}{*}{ Employees } & $\begin{array}{l}\text { Create employee-company conciliation committees to } \\
\text { settle any type of dispute, including those related to } \\
\text { unions (freedom to create and operate employee unions). }\end{array}$ & Committee created. \\
\hline & $\begin{array}{l}\text { Adapt facilities and work stations for people with } \\
\text { disabilities. }\end{array}$ & $\begin{array}{l}\text { Facilities and work stations } \\
\text { improved. }\end{array}$ \\
\hline & $\begin{array}{l}\text { Design a schedule of team-building and leisure activities } \\
\text { (recreational, cultural, and sports) for employees. }\end{array}$ & Schedule prepared. \\
\hline Customers & Adapt facilities for customers with disabilities. & Facilities improved. \\
\hline \multirow[t]{2}{*}{ Environment } & $\begin{array}{l}\text { Make an environmental statement in which the } \\
\text { organization publicly undertakes to prevent pollution, } \\
\text { combat climate change, and improve its environmental } \\
\text { performance. }\end{array}$ & $\begin{array}{l}\text { Environmental statement } \\
\text { made. }\end{array}$ \\
\hline & $\begin{array}{l}\text { Establish a management program with measurable } \\
\text { objectives and goals consistent with the environmental } \\
\text { commitment. }\end{array}$ & $\begin{array}{l}\text { Environmental program } \\
\text { established. }\end{array}$ \\
\hline \multirow{2}{*}{$\begin{array}{l}\text { Local } \\
\text { community }\end{array}$} & $\begin{array}{l}\text { Carry out regular awareness-raising campaigns for the } \\
\text { prevention of the commercial sexual exploitation of } \\
\text { children and adolescents. }\end{array}$ & $\begin{array}{l}\text { Campaigns carried out on an } \\
\text { ongoing basis. }\end{array}$ \\
\hline & $\begin{array}{l}\text { Promote local cuisine by including typical local dishes on } \\
\text { the menu, and promote the purchase of food supplies at } \\
\text { neighborhood businesses to boost the local economy. }\end{array}$ & $\begin{array}{l}\text { Menus designed, typical } \\
\text { dishes prepared, and food } \\
\text { ingredient purchases made. }\end{array}$ \\
\hline Investors & $\begin{array}{l}\text { Maintain a relationship based on transparency, loyalty, } \\
\text { and sustainable value creation with investors, making }\end{array}$ & $\begin{array}{lr}\text { Comprehensive } & \text { report } \\
\text { (financial, social, } & \text { and }\end{array}$ \\
\hline
\end{tabular}




\begin{tabular}{|c|c|c|}
\hline & $\begin{array}{l}\text { public the annual accounts, which should include the } \\
\text { financial, social, and environmental results. }\end{array}$ & $\begin{array}{l}\text { environmental) published } \\
\text { annually. }\end{array}$ \\
\hline \multirow{2}{*}{ Suppliers } & $\begin{array}{l}\text { Establish a purchasing policy based on ethical criteria and } \\
\text { compliance with economic, social, and environmental } \\
\text { aspects of CSR. }\end{array}$ & Policy document developed. \\
\hline & $\begin{array}{l}\text { Establish a policy of merit-based hiring of local suppliers } \\
\text { that includes compliance with economic, social, and } \\
\text { environmental aspects of CSR. }\end{array}$ & Policy document developed. \\
\hline Competitors & $\begin{array}{l}\text { Actively participate in business and industry associations } \\
\text { such as COTELCO [Colombian Hotel and Tourism } \\
\text { Association] for the promotion of aspects of common } \\
\text { interest in the industry, prioritizing issues related to CSR. }\end{array}$ & $\begin{array}{l}\text { Report on participation in } \\
\text { association activities. }\end{array}$ \\
\hline $\begin{array}{l}\mathrm{R} \& \mathrm{D} \text { and } \\
\text { innovation }\end{array}$ & $\begin{array}{l}\text { Sign cooperation agreements with academic institutions } \\
\text { for the formulation and implementation of } \mathrm{R} \& \mathrm{D} \text { and } \\
\text { innovation projects that promote improvement and } \\
\text { excellence in the areas of interest of the organization and } \\
\text { its stakeholders. }\end{array}$ & Agreements signed. \\
\hline Government & $\begin{array}{l}\text { Establish channels for communication and dialogue with } \\
\text { government agencies (local, regional, and national) in } \\
\text { order to cooperate on the development of a CSR policy } \\
\text { for the hotel industry that, in addition to including } \\
\text { incentives, promotes transparent business actions in the } \\
\text { area of CSR to the point of making it a natural and } \\
\text { industry-wide culture of action. }\end{array}$ & $\begin{array}{l}\text { Minutes of meetings with } \\
\text { government agencies and } \\
\text { draft policy developed. }\end{array}$ \\
\hline
\end{tabular}

Table 6. Improvement plans for medium hotels - Hme1 and Hme2

\begin{tabular}{|c|c|c|}
\hline $\begin{array}{l}\text { Management Area } \\
\text { - Stakeholder }\end{array}$ & Activity & Verification Source \\
\hline \multirow{3}{*}{ Senior management } & $\begin{array}{l}\text { Integrate CSR into the hotel's strategy, i.e., its mission, } \\
\text { vision, values, policy, and strategic plan. This latter } \\
\text { document should contain measurable CSR objectives } \\
\text { with comparable, verifiable, and assessable indicators. }\end{array}$ & $\begin{array}{l}\text { Mission, vision, values, } \\
\text { policy, and strategic plan } \\
\text { documents prepared. }\end{array}$ \\
\hline & $\begin{array}{l}\text { Develop a Code of Ethics that defines the organization's } \\
\text { conduct, behaviors, and principles of action. }\end{array}$ & Code of Ethics developed. \\
\hline & $\begin{array}{l}\text { Form a CSR committee, representative of all the hotel's } \\
\text { management areas, responsible for the comprehensive } \\
\text { management of CSR. }\end{array}$ & $\begin{array}{l}\text { Minutes recording the } \\
\text { formation of the committee } \\
\text { with functions. }\end{array}$ \\
\hline \multirow{3}{*}{ Employees } & $\begin{array}{l}\text { Conduct a workplace environment assessment at least } \\
\text { every two years and implement practical mechanisms } \\
\text { for continuous improvement. }\end{array}$ & $\begin{array}{l}\text { Workplace environment } \\
\text { report prepared. }\end{array}$ \\
\hline & $\begin{array}{l}\text { Make available to all members of the organization the } \\
\text { appropriate channels to submit suggestions or } \\
\text { complaints or report violations related to aspects of } \\
\text { CSR. }\end{array}$ & $\begin{array}{l}\text { Explanatory document } \\
\text { prepared. }\end{array}$ \\
\hline & $\begin{array}{l}\text { Carry out regular awareness-raising campaigns and/or } \\
\text { training sessions with employees on care for and } \\
\text { protection of the destination's environment. }\end{array}$ & $\begin{array}{l}\text { Campaigns and training } \\
\text { events held at least once a } \\
\text { month. }\end{array}$ \\
\hline Customers & $\begin{array}{l}\text { Carry out regular awareness-raising campaigns and/or } \\
\text { training sessions with customers on care for and } \\
\text { protection of the destination's environment. }\end{array}$ & $\begin{array}{l}\text { Campaigns and training } \\
\text { events carried out during } \\
\text { customers' stay. }\end{array}$ \\
\hline
\end{tabular}




\begin{tabular}{|c|c|c|}
\hline \multirow{2}{*}{ Environment } & $\begin{array}{l}\text { Design an early warning system for the identification of } \\
\text { environmental impacts that makes it possible to carry } \\
\text { out preventive and corrective actions in relation to them. }\end{array}$ & $\begin{array}{l}\text { Early warning system for the } \\
\text { identification of } \\
\text { environmental impacts } \\
\text { designed. }\end{array}$ \\
\hline & $\begin{array}{l}\text { Implement technical and technological systems to } \\
\text { promote the use of alternative energy, mainly, solar, } \\
\text { wind, and ocean. }\end{array}$ & $\begin{array}{l}\text { Technical and technological } \\
\text { systems implemented. }\end{array}$ \\
\hline \multirow[b]{2}{*}{ Local community } & $\begin{array}{l}\text { Carry out regular awareness-raising campaigns for the } \\
\text { prevention of the commercial sexual exploitation of } \\
\text { children and adolescents. }\end{array}$ & $\begin{array}{l}\text { Campaigns carried out on an } \\
\text { ongoing basis. }\end{array}$ \\
\hline & $\begin{array}{l}\text { Promote local culture through the use of decorative } \\
\text { elements that promote and encourage craftwork, the } \\
\text { organization of cultural immersion tours, and the } \\
\text { holding of on-site activities such as concerts, dances, } \\
\text { and craft shows. }\end{array}$ & $\begin{array}{l}\text { Local decorative crafts } \\
\text { installed in the hotel; } \\
\text { immersion tours and } \\
\text { activities of cultural interest } \\
\text { designed. }\end{array}$ \\
\hline Investors & $\begin{array}{l}\text { Maintain a relationship based on transparency, loyalty, } \\
\text { and sustainable value creation with investors, making } \\
\text { public the annual accounts, which should include the } \\
\text { financial, social, and environmental results. }\end{array}$ & $\begin{array}{l}\text { Comprehensive report } \\
\text { (financial, social, and } \\
\text { environmental) published } \\
\text { annually. }\end{array}$ \\
\hline \multirow[b]{2}{*}{ Suppliers } & $\begin{array}{l}\text { Establish a purchasing policy based on ethical criteria } \\
\text { and compliance with economic, social, and } \\
\text { environmental aspects of CSR. }\end{array}$ & Policy document developed. \\
\hline & $\begin{array}{l}\text { Establish a policy of merit-based hiring of local } \\
\text { suppliers that includes compliance with economic, } \\
\text { social, and environmental aspects of CSR. }\end{array}$ & Policy document developed. \\
\hline Competitors & $\begin{array}{l}\text { Maintain good relations with competitors, respecting } \\
\text { their property rights and cooperating transparently with } \\
\text { them. }\end{array}$ & $\begin{array}{l}\text { Report on joint activities } \\
\text { carried out with competitors. }\end{array}$ \\
\hline $\begin{array}{l}\text { R\&D and } \\
\text { innovation }\end{array}$ & $\begin{array}{l}\text { Sign cooperation agreements with academic institutions } \\
\text { for the formulation and implementation of R\&D and } \\
\text { innovation projects that promote improvement and } \\
\text { excellence in the areas of interest of the organization and } \\
\text { its stakeholders. }\end{array}$ & Agreements signed. \\
\hline Government & $\begin{array}{l}\text { Establish channels for communication and dialogue } \\
\text { with government agencies (local, regional, and national) } \\
\text { in order to cooperate on the development of a CSR } \\
\text { policy for the hotel industry that, in addition to including } \\
\text { incentives, promotes transparent business actions in the } \\
\text { area of CSR to the point of making it a natural and } \\
\text { industry-wide culture of action. }\end{array}$ & $\begin{array}{l}\text { Minutes of meetings with } \\
\text { government agencies and } \\
\text { draft policy developed. }\end{array}$ \\
\hline
\end{tabular}

Table 7. Improvement plans for large hotels - Hla1 and Hla2

\begin{tabular}{|c|l|l|}
\hline $\begin{array}{c}\text { Management Area - } \\
\text { Stakeholder }\end{array}$ & \multicolumn{1}{|c|}{ Activity } & \multicolumn{1}{|c|}{ Verification Source } \\
\hline Senior management & $\begin{array}{l}\text { Integrate CSR into the hotel's strategy, i.e., its mission, } \\
\text { vision, values, policy, and strategic plan. This latter } \\
\text { document should contain measurable CSR objectives with } \\
\text { comparable, verifiable, and assessable indicators. }\end{array}$ & $\begin{array}{l}\text { Mission, vision, values, } \\
\text { policy, and strategic plan } \\
\text { documents prepared. }\end{array}$ \\
\hline
\end{tabular}




\begin{tabular}{|c|c|c|}
\hline & $\begin{array}{l}\text { Join an international initiative on codes of conduct for the } \\
\text { promotion and protection of human rights, preferably that } \\
\text { of Amnesty International (Human Rights Principles for } \\
\text { Companies) or the United Nations (Guiding Principles on } \\
\text { Business and Human Rights). }\end{array}$ & $\begin{array}{l}\text { Document offering proof of } \\
\text { the commitment to one of } \\
\text { these codes of conduct. }\end{array}$ \\
\hline & $\begin{array}{l}\text { Form a CSR committee, representative of all the hotel's } \\
\text { management areas, responsible for the comprehensive } \\
\text { management of CSR. }\end{array}$ & $\begin{array}{l}\text { Minutes recording the } \\
\text { formation of the committee } \\
\text { with functions. }\end{array}$ \\
\hline \multirow{3}{*}{ Employees } & $\begin{array}{l}\text { Create employee-company conciliation committees to } \\
\text { settle any type of dispute, including those related to unions } \\
\text { (freedom to create and operate employee unions). }\end{array}$ & Committee created. \\
\hline & $\begin{array}{l}\text { Make available to all members of the organization the } \\
\text { appropriate channels to submit suggestions or complaints } \\
\text { or report violations related to aspects of CSR. }\end{array}$ & $\begin{array}{l}\text { Explanatory document } \\
\text { prepared. }\end{array}$ \\
\hline & $\begin{array}{l}\text { Carry out regular awareness-raising campaigns and/or } \\
\text { training sessions with employees on care for and } \\
\text { protection of the destination's environment. }\end{array}$ & $\begin{array}{l}\text { Campaigns and training } \\
\text { events held at least once a } \\
\text { month. }\end{array}$ \\
\hline Customers & $\begin{array}{l}\text { Carry out regular awareness-raising campaigns with } \\
\text { customers to promote respect for the heritage, values, } \\
\text { culture, and language of the local communities. }\end{array}$ & $\begin{array}{l}\text { Campaigns carried out } \\
\text { during customers' stay. }\end{array}$ \\
\hline \multirow[b]{2}{*}{ Environment } & $\begin{array}{l}\text { Design a strategy with specific activities to tackle global } \\
\text { warming (climate change). }\end{array}$ & Strategy document prepared. \\
\hline & $\begin{array}{l}\text { Implement technical and technological systems to } \\
\text { promote the use of alternative energy, mainly, solar, wind, } \\
\text { and ocean. }\end{array}$ & $\begin{array}{l}\text { Technical and technological } \\
\text { systems implemented. }\end{array}$ \\
\hline Local community & $\begin{array}{l}\text { Promote local culture through the use of decorative } \\
\text { elements that promote and encourage craftwork, the } \\
\text { organization of cultural immersion tours, and the holding } \\
\text { of on-site activities such as concerts, dances, and craft } \\
\text { shows. }\end{array}$ & $\begin{array}{l}\text { Local decorative crafts } \\
\text { installed in the hotel; } \\
\text { immersion tours and } \\
\text { activities of cultural interest } \\
\text { designed. }\end{array}$ \\
\hline Investors & $\begin{array}{l}\text { Maintain a relationship based on transparency, loyalty, } \\
\text { and sustainable value creation with investors, making } \\
\text { public the annual accounts, which should include the } \\
\text { financial, social, and environmental results. }\end{array}$ & $\begin{array}{l}\text { Comprehensive report } \\
\text { (financial, social, and } \\
\text { environmental) published } \\
\text { annually. }\end{array}$ \\
\hline Suppliers & $\begin{array}{l}\text { Encourage good business practice among suppliers by } \\
\text { providing support to them for compliance with } \\
\text { international fair-trade policies and for their proper } \\
\text { inclusion in leading organizations in this field, such as } \\
\text { Fair Trade International. }\end{array}$ & $\begin{array}{l}\text { Suppliers supported and } \\
\text { included in Fair Trade } \\
\text { International. }\end{array}$ \\
\hline Competitors & $\begin{array}{l}\text { Maintain good relations with competitors, respecting their } \\
\text { property rights and cooperating transparently with them. }\end{array}$ & $\begin{array}{l}\text { Report on joint activities } \\
\text { carried out with competitors. }\end{array}$ \\
\hline R\&D and innovation & $\begin{array}{l}\text { Sign cooperation agreements with academic institutions } \\
\text { for the formulation and implementation of } R \& D \text { and } \\
\text { innovation projects that promote improvement and } \\
\text { excellence in the areas of interest of the organization and } \\
\text { its stakeholders. }\end{array}$ & Agreements signed. \\
\hline Government & $\begin{array}{l}\text { Establish channels for communication and dialogue with } \\
\text { government agencies (local, regional, and national) in } \\
\text { order to cooperate on the development of a CSR policy for }\end{array}$ & $\begin{array}{l}\text { Minutes of meetings with } \\
\text { government agencies and } \\
\text { draft policy developed. }\end{array}$ \\
\hline
\end{tabular}




\begin{tabular}{|l|l|l|}
\hline & $\begin{array}{l}\text { the hotel industry that, in addition to including incentives, } \\
\text { promotes transparent business actions in the area of CSR } \\
\text { to the point of making it a natural and industry-wide } \\
\text { culture of action. }\end{array}$ & \\
\hline
\end{tabular}

\subsection{CSR management model proposed for the hotel industry}

In order to better manage and implement both the hotel tourism companies' CSR activities and their respective improvement plans, an industry-specific CSR model was designed, taking the following into account: i) with regard to codes, standards, guidelines, and guides, a total of 16 international CSR documents; ii) with regard to CSR theories, the ethicsbased SD theory; and iii) with regard to tourism, the content of the Global Code of Ethics for Tourism, as the main framework of reference worldwide for responsible and sustainable tourism promoted by the UNWTO, the industry's governing body.

Additionally, to make the implementation more applicable to the business reality of the hotel industry, ideas were adapted from the classical and practical PDCA cycle (plan-do-checkact) model for continuous improvement proposed by Deming (1989); in the general field of tourism, concepts were adapted from the models proposed by Hall (2000) and Mihalic (2016); and, in the specific field of the hotel industry, ideas were taken from the models proposed by Rey-Maquieira et al. (2011) and Peña and Serra (2012).

The main element of the proposed model is the ethical and moral framework of the organization, which, in practice, is carried out through compliance with universally accepted principles and social interests, such as ethics, human rights, labor standards, the environment, $\mathrm{SD}$, and justice, as well as the principles stipulated in the Global Code of Ethics for Tourism, thereby ensuring that the hotel companies in the study are more directly engaged with the welfare and development of the local host communities in their immediate area of influence. 
The proposed model is graphically depicted in Figure 1. The four component stages (plan, do, check, and act) that each hotel has to follow for the improvement plans to be successful are described in detail below.

Figure 1. CSR management model for the hotel industry

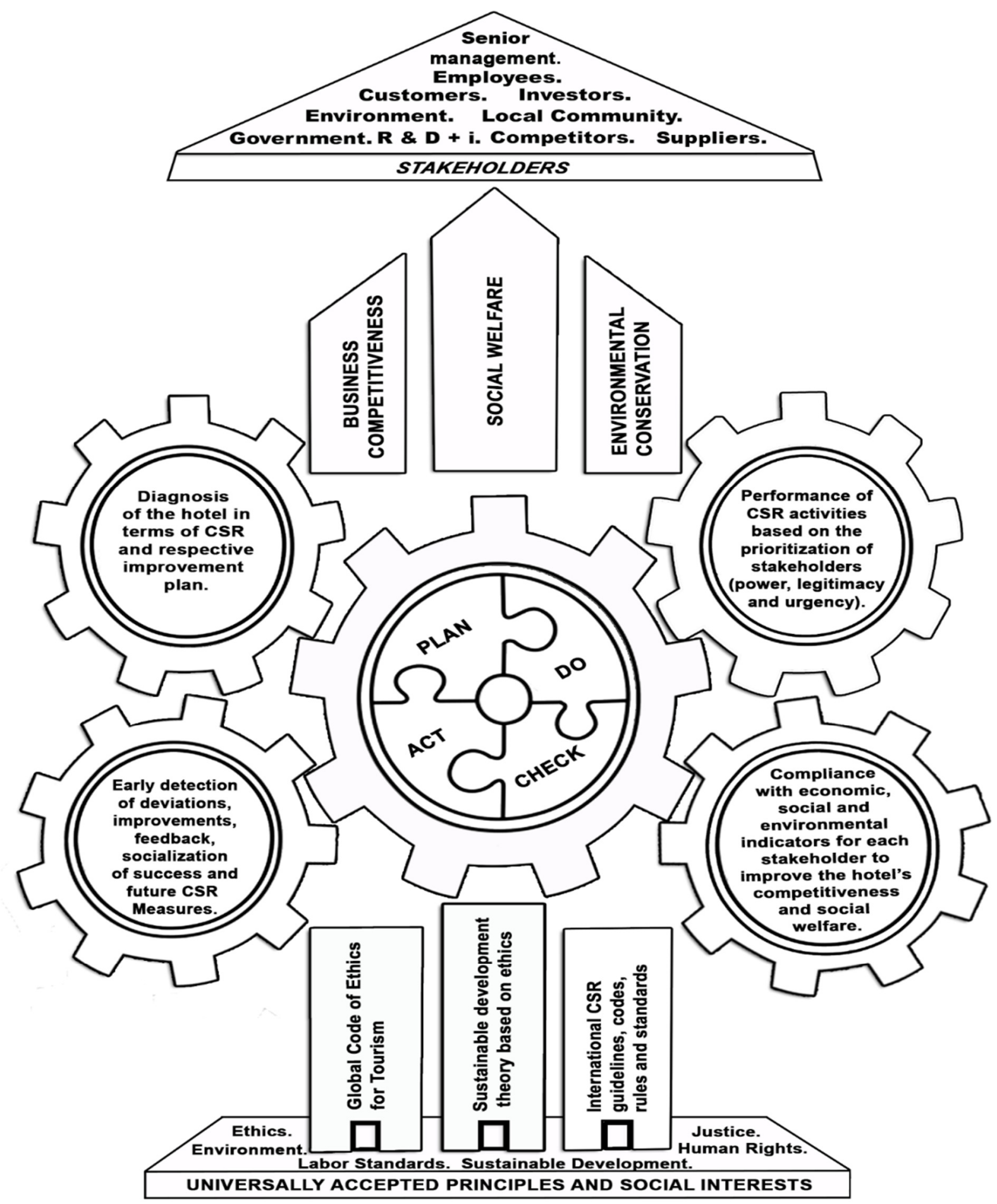


Plan. Based on its knowledge of its business in terms of CSR (diagnoses of CSR practices) and of its stakeholder relationships, the hotel company should identify those practices that yield the best result for both the company itself and the host society, i.e., those practices that create the most value for both of them. In practice, this means that the CSR actions identified by the company must necessarily improve its business competitiveness, social welfare, and environmental conservation. For the present study, the respective diagnosis for each of the eight hotel establishments has already been carried out (classification of the companies according to their CSR practices), and the corresponding CSR activities have been identified and are explained in the improvement plans described in Section 4.2.

Do. Once the CSR activities have been identified, they are prioritized for immediate implementation. This prioritization makes it possible to determine the specific order in which the CSR practices will be implemented, as it is done in accordance with the analysis of three criteria that define the types of relationships that companies have with their stakeholders, namely: power, referring to the influence that they are perceived to have over the business; legitimacy, related to establishing the extent to which their claims can be justified (e.g., through a contractual relationship); and urgency, which has to do with the seriousness of the problems that may arise and the need to apply the necessary correctives to solve them. In this regard, from a quantitative scale from 0 to 5 , being 0 nil and 5 maximum, each manager assessed the three criteria (power, legitimacy, urgency) for each of the stakeholders (see table 8), resulting in the following order, in terms of implementation of activities: senior management, employees, customers, the environment, the local community, investors, suppliers, competitors, R\&D and innovation, and, finally, government. The improvement plan activities were thus organized in this order. 
Table 8. Assessment of the criteria for prioritizing CSR activities on a scale of 0 to 5

\begin{tabular}{|c|c|c|c|c|c|c|c|c|c|c|c|c|}
\hline \multirow{3}{*}{ Stakeholder } & \multicolumn{4}{|c|}{$\begin{array}{l}\text { Hotels Hmi1, Hmi2, } \\
\text { Hsm1, Hsm2 }\end{array}$} & \multicolumn{4}{|c|}{ Hotels Hme1, Hme2 } & \multicolumn{4}{|c|}{ Hotels Hla1, Hla2 } \\
\hline & & & & & & & & & & & & \\
\hline & $\mathbf{P}$ & $\mathbf{L}$ & $\mathbf{U}$ & OAS & $\mathbf{P}$ & $\mathbf{L}$ & $\mathbf{U}$ & OAS & $\mathbf{P}$ & $\mathbf{L}$ & $\mathbf{U}$ & OAS \\
\hline Senior management & 5.0 & 5.0 & 5.0 & 5.0 & 4.5 & 5.0 & 5.0 & 4.8 & 4.5 & 4.5 & 4.5 & 4.5 \\
\hline Employees & 4.5 & 5.0 & 4.5 & 4.7 & 4.5 & 5.0 & 4.0 & 4.5 & 4.5 & 4.5 & 4.0 & 4.3 \\
\hline Customers & 4.5 & 5.0 & 4.0 & 4.5 & 4.5 & 5.0 & 3.5 & 4.3 & 4.0 & 4.5 & 4.0 & 4.2 \\
\hline Environment & 4.0 & 4.0 & 4.0 & 4.0 & 4.0 & 4.5 & 3.0 & 3.8 & 4.0 & 4.0 & 3.0 & 3.7 \\
\hline Local community & 4.0 & 3.5 & 4.0 & 3.8 & 4.0 & 4.0 & 3.0 & 3.7 & 3.5 & 3.0 & 4.0 & 3.5 \\
\hline Investors & 5.0 & 5.0 & 1.0 & 3.7 & 4.0 & 4.5 & 2.0 & 3.5 & 4.0 & 4.0 & 2.0 & 3.3 \\
\hline Suppliers & 3.5 & 3.5 & 3.0 & 3.3 & 3.0 & 3.5 & 3.0 & 3.2 & 3.0 & 3.0 & 3.0 & 3.0 \\
\hline Competitors & 3.0 & 3.0 & 3.0 & 3.0 & 2.5 & 3.0 & 3.0 & 2.8 & 2.5 & 2.5 & 2.5 & 2.5 \\
\hline R\&D and innovation & 2.5 & 2.5 & 2.5 & 2.5 & 2.0 & 2.5 & 2.5 & 2.3 & 2.0 & 2.0 & 2.0 & 2.0 \\
\hline Government & 2.0 & 2.5 & 2.0 & 2.2 & 2.0 & 2.0 & 2.0 & 2.0 & 2.0 & 2.0 & 1.5 & 1.8 \\
\hline
\end{tabular}

Notes: $\mathrm{P}=$ Power. $\mathrm{L}=$ Legitimacy. $\mathrm{U}=$ Urgency. OAS = Overall Average Score

Check. In this stage, the monitoring of the implementation of CSR practices is carried out and the degree of compliance is evaluated in percentage terms (0 to 100\%). Each practice is measured to determine whether the desired outcomes and improvements in the proposed issue have been achieved. Specifically, this stage helps the company determine with certainty whether it has reduced or eliminated the negative impacts, what benefits have been obtained, and which activities have delivered the most value for the company and the host society, that is, what impact each activity has had in terms of improving business competitiveness, social welfare, and environmental conservation. To determine this impact, it is necessary to measure the results of the CSR activities, to which end a series of indicators must be designed by the organization's social, environmental, and economic areas that have a direct relationship with its stakeholders (Camilleri, 2015). For the companies in this study, these indicators are defined in the respective proposed improvement plans. 
Act. In this final stage, the respective improvements are proposed and carried out, based on the results obtained in the previous stage, mainly in relation to the implementation of the CSR activities and their impact on the hotel establishments' economic, social, and environmental indicators and, ultimately, on business competitiveness, social welfare, and environmental conservation. In particular, detailed feedback is provided, both in terms of early detection of possible deviations that may arise and to highlight the successes achieved and open future avenues of action in the field of CSR.

In the light of this explanation of the proposed model, it is worth recalling that, as a result of growing stakeholder concern about SD, CSR has become key for the business sector, shifting the business model toward a new voluntary paradigm, based on natural resource conservation, social welfare, stakeholder engagement, and economic performance (Ait Sidhoum \& Serra, 2018). The goal of the proposed model is thus similarly to make CSR the essence of the strategic management of companies in a specific industry, namely, the hotel industry, so that the CSR actions of the establishments that make up the industry in the study area can more effectively contribute to environmental conservation and the social welfare of all their stakeholders, as well as improve their business competitiveness, which will undoubtedly generate the greatest benefit in the long term, both for them and for their host societies.

\section{Conclusions}

Although traditionally more polluting industries such as the oil and gas, chemical, paper, and mining industries are perceived by society as posing a higher environmental and social risk (Amor-Esteban, Galindo-Villardón, \& García-Sánchez, 2018), tourism has its own differentiating intangible characteristics because it is a consumer discretionary industry, meaning customers and people in general can easily stay away from its brands in the event of 
poor performance. Consequently, the industry should not ignore CSR (Kim, Lee, \& Kang, 2018); rather than taking the form of isolated one-off actions, it should be given a strategic focus, as it significantly helps attract and retain valuable employees (Camilleri, 2021; GligorCimpoieru et al., 2017), which is undeniably highly beneficial for the company.

Likewise, CSR practices are increasingly common due to a variety of social, environmental, and economic pressures (Zatwarnicka-Madura et al., 2019) and have advanced as a result of global changes and because of how their role in the promotion and support of SD is perceived (Li, Khalili, \& Cheng, 2019). In particular, CSR has become an important tool to achieve tourism competitiveness and sustainability, and industry and government should thus approach it as a long-term holistic concept (Andersen, Blichfeldt, \& Liburd, 2017), especially in those places in which tourism activities have emerged as a real alternative to solve structural problems such as unemployment and poverty, which normally occurs in developing countries.

In the hotel industry, Kim, Barber, and Kim (2019) have cited several studies that show a real connection between sustainability and CSR. In this regard, the present study has sought to offset the deficiencies in CSR actions in the hotel industry and foster awareness and a critical mass for its conceptual understanding and proper implementation - specifically at tourist accommodation companies in the city of Santa Marta (Colombia) - as a strategic tool that, in addition to helping to generate traditional economic benefits for businesses, makes it possible to better contribute to the social, environmental, and sustainable economic development of the communities located in their immediate surroundings and, thus, to destination sustainability and competitiveness.

Specifically, the identified, diagnosed, and evaluated CSR practices have placed the study hotels within a minimum, low, and medium range of implementation, classifying them within the groups of philanthropic-reactive, legal-reactive, and active companies. The study's 
findings also make it possible to conclude that, within the various dimensions of CSR, economic activities (mainly related to customers and the product) are given the most importance and highest scores, indicating that CSR has been understood as a means of wealth creation, a position that falls within the framework of the instrumental theories proposed by Garriga and Melé (2004). However, even though they were rated lower, several social activities focused on the local community and workers stood out, as did environmental activities to promote care and protection of the destination's environment.

In the light of these results, eight improvement plans were proposed (one for each hotel), intended to achieve a balance between the implementation of economic activities with that of environmental and social activities, placing emphasis on the management areas with the greatest impact on stakeholders, i.e., senior management, employees, customers, the environment, the local community, investors, suppliers, competitors, R\&D and innovation, and government. Each proposed activity was assigned a verification source that will make it possible to determine compliance with it, which may not take more than twelve months to accomplish.

Separately, the challenge of SD drives destinations and tourism companies to implement new management and operating models, with a vision focused on the concepts of ethics, competitiveness, and sustainability, making stakeholders - both external and internal - essential elements of the business strategies and constantly seeking to balance business profitability with the natural environment and society. Such a model will clearly generate more well-being and development in the communities in which tourism activity is carried out, since the decisions and actions taken in this area will always seek to improve business competitiveness, social welfare, and environmental conservation. 
For this reason, the main implication of this study is the proposal of a CSR management model for the hotel industry in the area that will make it possible to improve profitability, product quality, the physical and social environment, and customer and employee satisfaction with the accommodation companies, which positively contributes both to their competitiveness and sustainability and to the hotel industry and the tourism destination itself as a whole.

Regarding theoretical implications, first of all, this paper contributes to a better understanding of CSR practices in an important sector (tourism) of Latin American countries, as it is known, the focus of academic research in this issue has been in developed countries (Jamali \& Carroll, 2017). Secondly, it's important to state that in all hotels the economic activities received the highest and this raises a serious reflection, since CSR has been understood exclusively as a means for the creation of wealth, framing this type of actions within the instrumental theories described by Garriga \& Melé (2004). Nevertheless, it is relevant to note that the hotels in the study carry out certain activities (although they are not yet strategics) in the social and environmental dimensions, which can be framed within the ethical theories also proposed by Garriga \& Melé (2004) and specifically within the theory of SD, which becomes hopeful evidence for the future of the sector in the study area.

On the other hand, the study makes a twofold contribution to the field of CSR research in the hotel industry. First, it describes a study that can be replicated, given the clarity of the findings, by any researcher interested in the issue; second, it can be compared with other studies, making it possible to identify gaps and opportunities for future research that could improve the quality of this publication. In this regard, given that the study is limited to the perception of hotel managers, future research should examine the opinions that other hotel stakeholders have of CSR (Peña, Serra, \& Ramón, 2018), such as employees, guests and the local community, in order to establish a more comprehensive diagnosis of the topic in the area. Similarly, given the contribution of CSR to SD demonstrated in papers such as Moon (2007), future research should 
include other industries, which would improve the understanding and practice of CSR at a larger number of companies in the city of Santa Marta, making it a decisive factor for the SD of the local economy.

Additionally, growing stakeholder pressure requires companies to be transparent with regard to their CSR practices, and, in fact, companies are trying to communicate more on these issues to increase their legitimacy in the eyes of society (ElAlfy, Darwish, \& Weber 2020). It is thus essential to know how reliable the corporate reporting mechanisms are, analyzing the gap between CSR claims and its actual implementation (Font et al., 2012). Future research should therefore analyze factors that influence not only CSR practices, but also the communication thereof. In this regard, the study of the relationship between the gender variable in corporate management and CSR is an outstanding issue for accommodation establishments, as some studies (e.g., Pucheta-Martínez, Bel-Oms, \& Nekhili, 2019) have shown that the presence of women on company boards promotes reporting on CSR, contributing to transparency, a fundamental aspect for the social legitimation of companies (Camilleri, 2018).

In this sense, it could be argued that studies such as the present one make it possible to identify how wide the gap is between organizations' social claims and actual CSR practice, as it has conclusively revealed the difference between what the companies of the city of Santa Marta report in terms of CSR and what they actually do. Furthermore, it has done so in one of the most important sectors globally, namely, tourism, and, within it, in the most influential industry in terms of generating both positive and negative impacts for the host communities, namely, the hotel industry.

Finally, this research has taken an important step toward improving the strategic management of the CSR of the studied hotel establishments by proposing a model that clearly promotes the competitiveness and sustainability of a developing-country tourism destination 
(in this case, in Colombia), thereby helping to generate critical mass and applied knowledge in the field of so-called "third world" countries, narrowing the gap somewhat between them and developed countries in terms of CSR training and practice in the tourism industry.

\section{References}

AccountAbility, United Nations Environment Programme and Stakeholder Research Associates Canada Inc. (2006). De las palabras a la acción: El compromiso con los stakeholders. Manual para la práctica de las relaciones con los grupos de interés. Madrid.

Alwyn L., \& Kiyoteru T. (2012). Globalization and Commitment in Corporate Social Responsibility: Cross-National Analyses of Institutional and Political-Economy Effects. American Sociological Review, 77 (1), 69-98. https://doi.org/10.1177/0003122411432701

Amor-Esteban, V., Galindo-Villardón, M., \& García-Sánchez, I. (2018). Useful information for stakeholder engagement: A multivariate proposal of an Industrial Corporate Social Responsibility Practices Index. Sustainable Development, 26 (6), 620-637. https://doi.org/10.1002/sd.1732.

Ait Sidhoum, A., \& Serra, T. (2018). Corporate Sustainable Development: Revisiting the Relationship between Corporate Social Responsibility Dimensions. Sustainable Development, 26 (4), 365-378. https://doi.org/10.1002/sd.1711.

Andersen, I. M., Blichfeldt, B.S., \& Liburd, J. (2017). Sustainability in coastal tourism development: an example from Denmark. Current Issues in Tourism, 21, 1329-1336. https://doi.org/10.1080/13683500.2016.1272557

Annan, K. (1999). UN Global Compact. World Economic Forum. Davos, Switzerland. UN Press Release SG/SM/6881.

Argandoña, A., \& Hoivik, H. (2009). Corporate Social Responsibility: One Size Does Not Fit All. Collecting Evidence from Europe. Journal of Business Ethics, 89, 221-234. https://doi.org/10.1007/s10551-010-0394-4

Atehortúa, F. (2008). Responsabilidad Social Empresarial: Entre la ética discursiva y la $\begin{array}{lllll}\text { racionalidad técnica. } & \text { Revista } & \text { EAN, } & \text { 125-140. }\end{array}$ https://doi.org/10.21158/01208160.n62.2008.433

Bradbury, H. (2001). Learning with the natural step: action research to promote conversations for sustainable development. In: Reasons, P. and Bradbury, H., eds. Handbook of action research: participative enquiry and practice. London: Sage, 307-313.

Camilleri, M. A. (2015). Valuing stakeholder engagement and sustainability reporting. Corporate Reputation Review, 18(3), 210-222. 
Camilleri, M. A. (2017). Corporate sustainability and responsibility: creating value for business, society and the environment. Asian Journal of Sustainability and Social Responsibility, 2(1), 59-74.

Camilleri, M. A. (2018). Theoretical insights on integrated reporting: The inclusion of nonfinancial capitals in corporate disclosures. Corporate Communications: An International Journal.

Camilleri, M. A. (2019). The circular economy's closed loop and product service systems for sustainable development: A review and appraisal. Sustainable Development, 27(3), 530536.

Camilleri, M. A. (2020). European environment policy for the circular economy: Implications for business and industry stakeholders. Sustainable Development, 28(6), 1804-1812.

Camilleri, M. A. (2021). The Employees' State of Mind during COVID-19: A SelfDetermination Theory Perspective. Sustainability, 13(7), 3634.

Carroll, A.B. (1991). The pyramid of corporate social responsibility: toward the moral management of organizational stakeholders. Business Horizons, 34 (4), 39-48. https://doi.org/10.1016/0007-6813(91)90005-G

Carroll, A.B. (1999). Corporate Social Responsibility: Evolution of a definitional construction. Business and Society, 38, 268-295. https://doi.org/10.1177/000765039903800303

Casado, F., \& Roser, I. (2009). La RSE de la empresa española en América Latina. Madrid: Fundación Carolina-CeAlci, Documento de Trabajo No 34.

Cho, S.J., Chung, C.Y., \& Young, J. (2019). Study on the Relationship between CSR and Financial Performance. Sustainability, 11, 343. https://doi.org/10.3390/su11020343

Chomali, F., \& Majluf, N. (2007). Ética y Responsabilidad Social en la Empresa. Santiago: Aguilar Chilena de Ediciones S.A.

Chung, L.H., \& Parker, L.D. (2010). Managing social and environmental action and accountability in the hospitality industry: a Singapore perspective. Accounting Forum 34, 46-53. https://doi.org/10.1016/j.accfor.2009.10.003

Corral, A., Isusi, I., Peinado-Vara, E., \& Pérez, T. (2007). La Responsabilidad Social y Medioambiental de la Microempresa en Latinoamérica. Brussels: Ikei research and consultancy.

De George, R. (1987). The status of business ethics: Past and future. Journal of Business Ethics 1987, 6, 201-211. https://doi.org/10.1007/BF00382865

Deming, W.E. (1989). Calidad, Productividad y Competitividad: la salida de la crisis. Ediciones Díaz de Santos. Madrid. 
Drucker, P. (1984). Converting social problems into business opportunities: The new meaning of Corporate Social Responsibility. California Management Review 1984, 26, 53-63. $10.2307 / 41165066$

Ehsan, S., Nazir, M.S., Nurunnabi, M., Raza Khan, Q., Tahir, S., \& Ahmed, I. (2018). A Multimethod Approach to Assess and Measure Corporate Social Responsibility Disclosure and Practices in a Developing Economy. Sustainability, 10, 2955. https://doi.org/10.3390/su10082955.

Eisenhardt, K.M. (1989). Building Theories from Case Study Research. Academy of Management Review, 14 (4), 532-550. 10.2307/258557

ElAlfy, A., Darwish, K.M., \& Weber, O. (2020). Corporations and sustainable development goals communication on social media: Corporate social responsibility or just another buzzword? Sustainable Development, 28 (5), 1418-1430. https://doi.org/10.1002/sd.2095.

Eme, J. E., Obal, U. E. U., Inyang, O. I., \& Effiong, C. (2013). Corporate social responsibility in small and medium scale enterprises in Nigeria: An example from the hotel industry. International Journal of Business and Management, 8 (14), 119-126. 10.5539/ijbm.v8n14p119

Font, X. (2008). Sostenibilidad y Alivio de la Pobreza en Países en vía de desarrollo. Estudios y Perspectivas en Turismo, 17, 17-28.

Font, X., \& Lynes, J. (2018). Corporate social responsibility in tourism and hospitality. Journal $\begin{array}{lllll}\text { of Sustainable } & \text { Tourism, } & 26 & \text { (7), } & \text { 1027-1042. }\end{array}$ https://doi.org/10.1080/09669582.2018.1488856.

Font, X., Guix, M., \& Bonilla-Priego, M. (2016). Corporate social responsibility in cruising: Using materiality analysis to create shared value. Tourism Management, 53, 175-186. https://doi.org/10.1016/j.tourman.2015.10.007

Font, X., Walmsley, A., Cogotti, S., McCombes, L., \& Häusler, N. (2012). Corporate social responsibility: The disclosure-performance gap. Tourism Management, 33, 1544-1553. https://doi.org/10.1016/j.tourman.2012.02.012

Forum Empresa (2011). El Estado de la Responsabilidad Social Empresarial en América Latina. Panama City.

Freeman R.E. (1984). Strategic management: A Stakeholders Approach. Pitman. Boston.

Freeman R.E., \& Reed, D.L. (1983). Stockholders and Stakeholders: A new perspective on Corporate Governance. California Management Review, 25 (3), 88-106. https://doi.org/10.2307/41165018

Garay, L., \& Font, X. (2012). Doing good to do well? Corporate social responsibility reasons, practices and impacts in small and medium accommodation enterprises. International Journal of Hospitality Management, $31 \quad$ (2), 329-337. https://doi.org/10.1016/j.ijhm.2011.04.013 
Garriga, E., \& Melé, D. (2004). Corporate Social Responsibility Theories: Mapping the Territory. Journal of Business Ethics, 53, 51-71. https://doi.org/10.1023/B:BUSI.0000039399.90587.34

Gligor-Cimpoieru, D.C., Munteanu, V.P., Niţu-Antonie, R.D., Schneider, A., \& Preda, G. (2017). Perceptions of Future Employees toward CSR Environmental Practices in Tourism. Sustainability, 9, 1631. https://doi.org/10.3390/su9091631.

Global Reporting Initiative - GRI (2013). G4 Sustainability Reporting Guidelines. Reporting principles and standard disclosures. Amsterdam.

González, E., Alén, M., \& Rodríguez, L. (2011). Benchmarking en responsabilidad social corporativa. El caso de las empresas gallegas. Cuadernos de Gestión, 11, 101-119. $10.5295 / \mathrm{cdg} .100226 \mathrm{eg}$

Guédez, V. (2010). Responsabilidad Social Empresarial. Visiones Complementarias. Hacia un Modelaje Social. Caracas: Cámara Venezolano Americana de Comercio e Industria Venamcham.

Hall, C.M. (2000). Tourism Planning: Policies, Processes and Relationships. Prentice Hall. Essex.

Jamali, D., \& Carroll, A. (2017). Capturing advances in CSR: Developed versus developing country perspectives. Business Ethics: A European Review, 26 (4), 321-325.

Kaku, R., (1997). The path of Kyosei. Harvard Business Review, 75 (4), 55-66.

Kim, B., Lee, S., \& Kang, K.H. (2018). The moderating role of CEO narcissism on the relationship between uncertainty avoidance and CSR. Tourism Management, 67, 203-213. https://doi.org/10.1016/j.tourman.2018.01.018.

Kim Y. H., Barber N., \& Kim, D.-K. (2019). Sustainability research in the hotel industry: Past, present, and future. Journal of Hospitality Marketing \& Management, 28 (5), 576-620 https://doi.org/10.1080/19368623.2019.1533907

Ladkin, D., (2005). Action Research. In: Seale, C., Gobo, G., Gubrium, J.F., \& Silverman, D., eds. Qualitive Research Practice. London: Sage, 536-548.

Lee, Ch-K., Kim, J., \& Kim, J.S. (2018). Impact of a gaming company's CSR on residents' perceived benefits, quality of life, and support. Tourism Management, 64, 281-290. http://dx.doi.org/10.1016/j.tourman.2014.12.015

Lee, S., Seo, K., \& Sharma, A. (2013). Corporate social responsibility and firm performance in the airline industry: The moderating role of oil prices. Tourism Management, 38, 20-30. https://doi.org/10.1016/j.tourman.2016.12.011

Li, K., Khalili, N.R., \& Cheng, W. (2019). Corporate Social Responsibility Practices in China: Trends, Context, and Impact on Company Performance. Sustainability 2019, 11, 354. https://doi.org/10.3390/su11020354 
Mihalic, T. (2016). Sustainable-responsible tourism discourse - Towards 'responsustable' tourism. Journal of Cleaner Production, 111, 461-470. https://doi.org/10.1016/j.jclepro.2014.12.062

Mitchell, R. K., Agle, B. R., \& Wood, D. J (1997). Toward a theory of stakeholder identification and salience: Defining the principle of who and what really counts. Academy of Management Review, 22, 853-86. 10.2307/259247

Moon, J. (2007). The contribution of corporate social responsibility to sustainable development. Sustainable Development, 15 (5), 296-306. https://doi.org/10.1002/sd.1732.

Murphy P. (1978). An evolution: Corporate Social Responsiveness. Business Review, 30, 1925.

Park, E., \& Kim, K.J. (2019). What drives "customer loyalty"? The role of corporate social responsibility. Sustainable Development, 27 (3), 304-311. https://doi.org/10.1002/sd.1901

Park, S., Song, S., \& Lee, S. (2017). Corporate social responsibility and systematic risk of restaurant firms: The moderating role of geographical diversification. Tourism Management, 59, 610-620. https://doi.org/10.1016/j.tourman.2016.09.016

Peña, D., Arteaga, J., \& Ramón, J. (2019). Determinants of CSR Application in the Hotel Industry of the Colombian Caribbean. Sustainability, 11, 5045. https://doi.org/10.3390/su11185045

Peña, D., Serra A. \& Ramón J. (2018). La práctica de la ética mediante la Responsabilidad Social Empresarial como elemento fundamental para el desarrollo sostenible de territorios con vocación turística. In: Tribiño L. and Ochoa, F. eds. Debates contemporáneos sobre el turismo - Tomo IV: Ética y buen vivir. Reflexiones actuales para la planificación y gestión del turismo. Bogotá: Editorial Universidad Externado de Colombia, 52-72.

Peña, D., \& Serra A. (2012). Responsabilidad Social Empresarial en el sector turístico. Estudio de caso en empresa de alojamiento de la ciudad de Santa Marta, Colombia. Estudios y Perspectivas en Turismo, 21, 1456-1480.

Porter, M., \& Kramer, M. (2002). The Competitive Advantage of Corporate Philanthropy. Harvard Business Review, reprint R0212D, 5-16.

Porter, M., \& Kramer, M. (2006). Strategy and Society: The Link between Competitive Advantage and Corporate Social Responsibility. Harvard Business Review, reprint R0612D, $1-14$.

Porter, M., \& Kramer, M. (2011). Creating Shared Value. How to reinvent capitalism and unleash a wave of innovation and growth. Harvard Business Review, reprint R1101C, 3-17.

Pucheta-Martínez, M., Bel-Oms, I., \& Nekhili, M. (2019). The contribution of financial entities to the sustainable development through the reporting of corporate social responsibility information. Sustainable Development, 27 (3), 388-400. https://doi.org/10.1002/sd.1901. 
Rey-Maquieira, J., Aguiló, E., González, A., Ramos, V., \& Razumoba, M. (2011). Responsabilidad Social Empresarial como una herramienta estratégica en las Empresas de Alojamiento. Centro de Investigación y Desarrollo para el Turismo - CITUR y Imagine Tourism Consultancy and Research. Palma de Mallorca.

Roadmap excelencia y responsabilidad (2010). Estudio de Responsabilidad Social Empresarial en las empresas turísticas de la Provincia de Málaga. Malaga.

Sasía P., \& Valor C. (2007). Partenariado, Relaciones Institucionales y RSC del Programa de Gestión Directiva de Organizaciones no Lucrativas. UNED and Fundación Luis Vives: Madrid.

Sepúlveda, J., Quintero, I., Lizcano, T., \& Díaz, E. (2013). Perfil de responsabilidad social empresarial del sector de calzado de la ciudad de Bucaramanga, Colombia. Revista Virtual Universidad Católica del Norte, 39, 212-226.

Sepúlveda, J., Ordoñez, F., \& Prada, C. (2014). Perfil de responsabilidad social empresarial del sector hotelero de la Ciudad de Bucaramanga - Colombia. Estudios y Perspectivas en Turismo, 39, 23-39.

Serra, A., Peña, D., Ramón, J., \& Martorell, O. (2018). Progress in research on CSR and the hotel industry (2006-2015). Cornell Hospitality Quarterly, 59, 15-38. https://doi.org/10.1177/1938965517719267.

Su, L., \& Swanson, S.R. (2017). The effect of destination social responsibility on tourist environmentally responsible behavior: Compared analysis of first time and repeat tourists. Tourism Management, 60, 308-321. https://doi.org/10.1016/j.tourman.2016.12.011

Tepelus, C.M. (2008). Destination Unknown? The Emergence of Corporate Social Responsibility for Sustainable Development of Tourism. PhD thesis. Lund University. Lund, Sweden.

Van Der Duim, R., \& Van Marwijk, R. (2006). The implementation of environmental management system for Dutch tour operators: an actor-network perspective. Journal for Sustainable Tourism, 14, 449-472. https://doi.org/10.2167/jost559.0

Vives, A., Corral, A. \& Isusi, I. (2005). Responsabilidad Social de la Empresa en las PyMEs de Latinoamérica. Washington.: Inter-American Development Bank (IDB) and Ikei research and consultancy.

Wells, V.K., Manika, D., Gregory-Smith, D., Taheri, B., \& McCowlen, C. (2015). Heritage tourism, CSR and the role of employee environmental behaviour. Tourism Management, 48, 399-413. https://doi.org/10.1016/j.tourman.2014.12.015

Yepes, G., Peña W., \& Sánchez, L (2007). Responsabilidad Social Empresarial. Fundamentos y aplicación en las organizaciones de hoy. Universidad Externado de Colombia. Bogota.

Yin, R.K. (2003). Case study research: design and methods. Applied Social Research Methods Series (3rd ed.). Sage Publications. Newbury Park, California. 
Zadek, S., Sabapathy, J., \& Dossing, H. (2003). Responsible Competitiveness, Corporate Responsibility Clusters in Action. AccountAbility \& The Copenhagen Centre: London.

Zatwarnicka-Madura, B., Siemieniako, D., Glińska, E., \& Sazonenka, Y. (2019). Strategic and Operational Levels of CSR Marketing Communication for Sustainable Orientation of a Company: A Case Study from Bangladesh. Sustainability, 11, 555. https://doi.org/10.3390/su11020555

Zhu, L., Zhan, L., \& Shaobo, K.L. (2020). Sustainable development reasonable for tourism destinations? An empirical study of the relationship between environmental competitiveness and tourism growth. Sustainable Development, version of record online 15 September. https://doi.org/10.1002/sd.2131 